\title{
GIANT CELL ARTERITIS: A DIAGNOSTIC CHALLENGE IN AN OLDER ADULT
}

\section{Arterite de células gigantes: um desafio diagnóstico em um idoso}

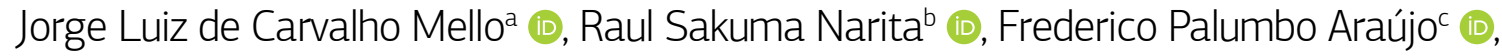 \\ Diba Maria Sebba Tosta de Souzad ${ }^{\mathbb{D}}$, Vitor Angelo Carluccio Galhardo ${ }^{\mathrm{e}}$
}

Giant cell arteritis is a large-vessel vasculitis usually seen in older adults. The inflammatory process results in systemic, ophthalmic, and neurological lesions. It is difficult to diagnose in older adults and may present as a medical emergency. Here, we report the case of an 83-year-old woman who presented with bitemporal headache, jaw claudication, glossodynia, failure to thrive, and amaurosis fugax. The findings supported the hypothesis of giant cell arteritis. Despite receiving treatment, the patient died of an acute myocardial infarction. Headache in older adults raises the possibility of giant cell arteritis, especially when combined with an ophthalmic emergency. Many symptoms indicate the condition, but the diagnosis may be challenging, especially for the generalist physician.

KEYWORDS: giant cell arteritis; frail older adults; vasculitis.

A arterite de células gigantes é uma vasculite de grandes vasos geralmente observada em adultos mais velhos. O processo inflamatório resulta em lesões sistêmicas, oftalmológicas e neurológicas. É de difícil diagnose em adultos mais velhos e pode se apresentar como uma emergência médica. Apresentamos o caso de uma mulher de 83 anos que apresentou cefaleia bitemporal, claudicação da mandíbula, glossodinia, incapacidade de prosperar e amaurose fugaz. Os resultados apoiaram a hipótese de arterite de células gigantes. Apesar de receber tratamento, o paciente morreu por infarto agudo do miocárdio. Dor de cabeça em idosos aumenta a possibilidade de arterite de células gigantes, especialmente quando combinada com uma emergência oftalmológica. Muitos sintomas indicam a condição, mas o diagnóstico pode ser desafiador, especialmente para o médico generalista.

PALAVRAS-CHAVE: arterite de células gigantes; idoso fragilizado; vasculite.

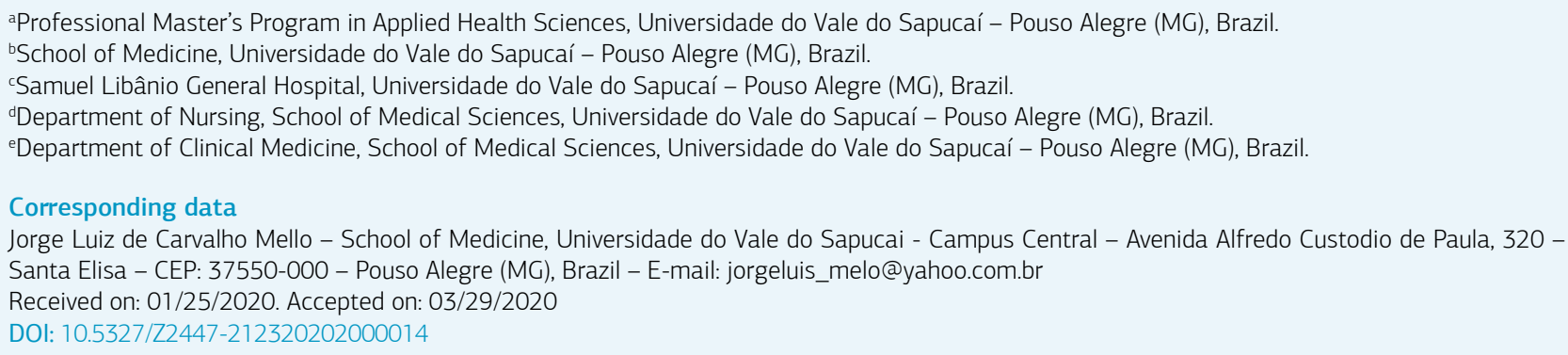




\section{INTRODUCTION}

Giant cell arteritis (GCA) is a large-vessel vasculitis usually seen in older adults over 50 years of age ${ }^{1}$ (mean age is about 70 years) and 2.5 times more likely to occur in women than men. ${ }^{2}$ Human leukocyte antigen (HLA) class II is involved in the pathophysiology of GCA, and dysregulated interactions between the vessel wall and immune cells are responsible for the development of large-vessel vasculitis. ${ }^{3}$ The inflammatory process results in systemic, ophthalmic, and neurological lesions manifested as headache, jaw and tongue claudication, tinnitus, neck pain, and visual impairment. ${ }^{1,2}$ Suspicion of GCA is a medical emergency requiring rapid diagnosis and treatment to prevent degenerative changes associated with vessel inflammation. ${ }^{2}$

This study reports a challenging case of CGA in an older patient that resulted in death despite treatment.

\section{PATIENT INFORMATION \& CLINICAL FINDINGS}

An 83-year-old woman with preserved cognition (MiniMental State Examination), functionally independent (Lawton Index and Katz Index), with comorbidities, receiving losartan (50 mg/day) for hypertension, duloxetine ( $30 \mathrm{mg} /$ day) for major depression, and risedronate ( $35 \mathrm{mg} / \mathrm{week}$ ) for osteoporosis sought treatment after 20 days experiencing bitemporal headache, jaw claudication, glossodynia, failure to thrive, and episodes of amaurosis fugax.

\section{DIAGNOSTIC ASSESSMENT}

Medical and dental examinations were performed. Physical examination revealed thickened temporal arteries and ophthalmoscopy showed a pale papilla in the right eye. Erythrocyte sedimentation rate (ESR) was $140 \mathrm{~mm} / \mathrm{h}$ and C-reactive protein (CRP) level was $160 \mathrm{mg} / \mathrm{L}$. As the findings supported the hypothesis of GCA, the patient was hospitalized for methylprednisolone pulse therapy and temporal artery biopsy, which confirmed GCA diagnosis (Figure 1).

\section{THERAPEUTIC INTERVENTION}

She was discharged on prednisone $(60 \mathrm{mg} /$ day $)$ with clinical and laboratory improvement. At follow-up, because of corticosteroid-induced complications and weaning difficulties, she was given methotrexate $(10 \mathrm{mg} /$ week $)$, which was discontinued due to the development of pericardial effusion. After stabilization, subcutaneous tocilizumab (162 mg/ week) was introduced.

\section{FOLLOW-UP AND OUTCOMES}

However, the patient died of an acute myocardial infarction with ST-segment elevation (clinical and electrocardiographic diagnosis).

In the differential diagnosis the following conditions were excluded: infectious causes (endocarditis - normal echocardiogram; hepatitis $\mathrm{B}$ and $\mathrm{C}$ - normal serologies); malignancy (multiple myeloma - normal protein electrophoresis); connective tissue diseases and other vasculitis (normal antinuclear antibody and normal antineutrophil cytoplasmic antibody); stroke (absence of cerebral infarctions in cranial computed tomography).

\section{DISCUSSION}

Typical symptoms of GCA include headaches, scalp tenderness, and jaw claudication, but constitutional symptoms are common, such as malaise, fatigue, weight loss, anorexia, and low-grade fever. ${ }^{2}$ Headaches and scalp tenderness tend to occur prior to the onset of visual loss, which has been reported to manifest in about $30 \%$ of cases and to be permanent in about $10-15 \%{ }^{2,4}$ More than $50 \%$ of patients develop polymyalgia rheumatica. Fever of unknown origin and failure to thrive are rare but possible presentations in older persons. ${ }^{2}$ In the reported case, the classic symptoms of GCA were present, including jaw claudication, which caused the patient to first consult a dentist rather than a physician, delaying diagnosis.

Evidence of an acute phase response is shown through raised ESR and/or CRP. ${ }^{5}$ Combination of ESR and CRP is being used to provide the highest sensitivity and specificity for the diagnosis of GCA. Laboratory tests have limited sensitivity for GCA: CRP $86.9 \%$ and ESR $84.1 \%$. Both combined provided a specificity of $97 \%$, but it was shown that they might be normal in GCA, as ESR was normal in 5-30\% of patients. ${ }^{6,7}$

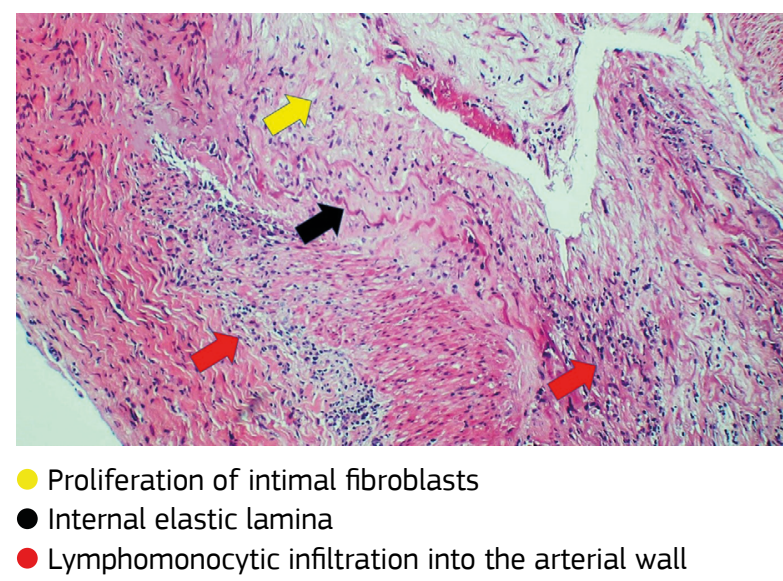

Figure 1 Histological section of the temporal artery (original magnification, $\mathrm{x} 100$ ). 
Ultrasound has been increasingly used as part of the assessment of patients with suspected GCA. ${ }^{8}$ Monti et al. ${ }^{9}$ found that ultrasound had a sensitivity of $63 \%$ and a specificity of $100 \%$ in routine clinical practice. Introduction of this technique in their center led to a decrease in biopsy rate from 42 to $24 \%$.

Temporal artery biopsy is the gold standard for diagnosis, although false negative results may occur in $30 \%$ of cases. ${ }^{4}$ The presence of multinucleated cells, as found in the present case, is not required for diagnosis.

GCA is considered a medical emergency, and patients need to be treated with high-dose prednisone or methylprednisolone pulse therapy as soon as possible. ${ }^{2}$ Glucocorticosteroids are the mainstay of treatment in GCA. Symptoms usually reduce substantially within a week. If patients present with any visual complications, they will require intravenous methylprednisolone $500 \mathrm{mg}$ to $1 \mathrm{~g}$ for 3 days before starting oral steroids. ${ }^{8}$

Tocilizumab is a humanized monoclonal antibody that has been shown to induce and maintain remission of GCA.,10 The National Institute for Health and Care Excellence (NICE) published a guideline allowing the treatment of GCA with tocilizumab for refractory or relapsing disease. This decision was made following the publication of studies ${ }^{8,11}$ showing that treatment with tocilizumab plus glucocorticosteroids in tapering scheme was superior to placebo. To be eligible for tocilizumab the patient needs to have a diagnosis confirmed by biopsy and/or imaging. ${ }^{12}$

Patients with GCA have a four times higher risk of developing myocardial infarction. ${ }^{2}$ The patient in this study died of acute myocardial infarction despite receiving treatment for GCA.
The most feared long-term complication of GCA is permanent visual loss; therefore, it is very important to recognize the symptoms promptly and treat patients with suspected GCA. Aortic dissection and stroke have also been described but are less common. ${ }^{13}$

Headache combined with an ophthalmic emergency in older adults raise the possibility of GCA diagnosis. Many symptoms and signs indicate the condition, but the diagnosis may be challenging in clinical practice, especially for the generalist physician.

\section{CONFLICT OF INTERESTS}

The authors declare no conflict of interests.

\section{FUNDING}

None.

\section{RESEARCH ETHICS}

The study was performed in accordance with the ethical standards of the 1964 Declaration of Helsinki and its subsequent amendments.

\section{PARTICIPANT CONSENT}

Written informed consent for publication of clinical details and clinical images was obtained from the patient and proxy.

\section{REFERENCES}

1. Lie JT. Aortic and extracranial large vessel giant cell arteritis: a review of 72 cases with histopathologic documentation. Semin Arthritis Rheum. 1995;24(6):422-31. https://doi.org/10.1016/s0049-0172(95)80010-7

2. Winkler A, True D. Giant Cell Arteritis: 2018 Review. Mo Med. 2018;115(5):468-70

3. Carmona FD, Mackie SL, Martín JE, Taylor JC, Vaglio A, Eyre S, et al. A large-scale genetic analysis reveals a strong contribution of the HLA class II region to giant cell arteritis susceptibility. J Am J Hum Gene. 2015;96(4):565-80. https://doi.org/10.1016/j.ajhg.2015.02.009

4. Borchers AT, Gershwin ME. Giant cell arteritis: a review of classification, pathophysiology, geoepidemiology and treatment. Autoimmun Rev. 2012;11(6-7):A544-54. https://doi.org/10.1016/j.autrev.2012.01.003

5. Ing E, Lahaie Luna G, Toren A, Ing R, Chen JJ, Arora N, et al. Multivariable prediction model for suspected giant cell arteritis: development and validation. Clin Ophthalmol. 2017;11:2031-42. https://doi.org/10.2147/ OPTH.S151385

6. Grzybowski A, Justynska A. Giant cell arteritis with normal ESR and/or CRP is rare, but not unique! Eye (Lond). 2013;27(12):1418-9. https:// doi.org/10.1038/eye.2013.208

7. Quick V, Kirwan J. Anti-Glomerular Basement Membrane Disease. In: Younger DS, editor. The vasculitidies, general considerations and systemic vasculitis. New York: Nova Science; 2015. v.1. p.311-36.
8. Lazarewicz K, Watson P. Giant cell arteritis. BMJ. 2019:365:11964 https://doi.org/10.1136/bmj.l1964

9. Monti S, Floris A, Ponte CB, Schmidt WA, Diamantopoulos AP, Pereira $C$, et al. The proposed role of ultrasound in the management of giant cell arteritis in routine clinical practice. Rheumatology (Oxford). 2018;57(1):112-9. https://doi.org/10.1093/rheumatology/kex341

10. Roberts J, Clifford A. Update on the management of giant cell arteritis. Ther Adv Chronic Dis. 2017;8(4-5):69-79. https://doi. org/10.1177/2040622317700089

11. Villiger PM, Adler S, Kuchen S, Wermelinger F, Dan D, Fiege V, et al. Tocilizumab for induction and maintenance of remission in giant cell arteritis: a phase 2, randomised, double-blind, placebo-controlled trial. Lancet. 2016;387(10031):1921-7. https://doi.org/10.1016/ S0140-6736(16)00560-2 26952547

12. Stone $\mathrm{JH}$, Klearman $\mathrm{M}$, Collinson N. Trial of tocilizumab in giant-cell arteritis. N Engl J Med. 2017;377(15):1494-5. https://doi.org/10.1056/ NEJMc1711031

13. Nuenninghoff DM, Hunder GG, Christianson TJH, McClelland RL, Matteson EL. Incidence and predictors of large-artery complication (aortic aneurysm, aortic dissection, and/or large-artery stenosis) in patients with giant cell arteritis: a population-based study over 50 years. Arthritis Rheum. 2003;48(12):3522-31. https://doi.org/10.1002/ art.11353 